\title{
PENGARUH STRATEGI GUIDED DISCOVERY LEARNING TERHADAP HASIL BELAJAR IPA DITINJAU DARI KEMAMPUAN BERPIKIR KRITIS SISWA KELAS IV ABIANSEMAL KABUPATEN BADUNG
}

\author{
Komala Dewi', N. Dantes ${ }^{2}$, I.B. Arnyana ${ }^{3}$ \\ Program Studi Pendidikan Dasar, Program Pascasarjana \\ Universitas Pendidikan Ganesha \\ Singaraja, Indonesia
}

e-mail: (komala.dewi,dantes,putu.aryana)@pasca.undikhsa.ac.id,

\begin{abstract}
Abstrak
Penelitian ini bertujuan untuk mengetahui besarnya pengaruh strategi guided discovery learning terhadap hasil belajar IPA ditinjau dari kemampuan berpikir kritis siswa kelas IV SD Gugus VII Abiansemal Kabupaten Badung. Jenis penelitian ini merupakan eksperimen semu (quasi eksperimen) dengan desain Post Test Only Control Group Design. Populasi dalam penelitian ini adalah seluruh siswa kelas IV SD Gugus VII Abiansemal Badung Tahun 2018/2019 yang terdiri dari 208 siswa. Sebanyak 38 siswa dipilih sebagai sampel yang ditentukan dengan teknik group random sampling. Data dianalisis dengan menggunakan analisis Anava dua jalan berbantuan SPSS 17.00 for windows. Hasil Penelitian menunjukkan bahwa: Pertama, terdapat pengaruh yang signifikan penerapan strategi guided discovery learning terhadap hasil belajar IPA pada siswa kelas IV SD Gugus VII Abiansemal Badung. Kedua, terdapat pengaruh interaksi yang signifikan antara strategi pembelajaran dengan kemapuan berpikir kritis terhadap hasil belajar IPA pada siswa Kelas IV SD Gugus VII Abiansemal Badung. Ketiga, terdapat pengaruh yang signifikan strategi guided discovery learning terhadap hasil belajar IPA pada siswa Kelas IV SD Gugus VII Abiansemal Badung yang memiliki kemampuan berpikir kritis tinggi. Kempat, terdapat pengaruh yang signifikan strategi guided discovery learning terhadap hasil belajar IPA pada siswa Kelas IV SD Gugus VII Abiansemal Badung Tahun 2018/2019 yang memiliki kemampuan berpikir kritis rendah.
\end{abstract}

Kata kunci: guided discovery learning, hasil belajar IPA, kemampuan berpikir kritis

\begin{abstract}
This study aims to determine the magnitude of the influence of guided discovery learning strategies on science learning outcomes in terms of critical thinking skills of fourth grade students of SD Gugus VII Abiansemal Badung Regency. This type of research is a quasiexperimental (quasi-experimental) design with Post Test Only Control Group Design. The population in this study were all fourth grade students of SD Group VII Abiansemal Badung Year 2018/2019 which consisted of 208 students. A total of 38 students were selected as samples determined by group random sampling technique. Data were analyzed using analysis of two-way Anava assisted SPSS 17.00 for windows. The results of the study show that: First, there is a significant effect of the implementation of guided discovery learning strategies on science learning outcomes in fourth grade students of SD Cluster VII Abiansemal Badung. Second, there is a significant interaction effect between learning strategies and the ability to think critically towards learning outcomes of science in students of Class IV SD Group VII Abiansemal Badung. Third, there is a significant effect of guided discovery learning strategies on science learning outcomes in Class IV SD Group VII Abiansemal Badung students who have high critical thinking skills. Fourth, there is a significant effect of guided discovery learning strategy on science learning outcomes in Class IV SD Class IV SD Group VII Abiansemal Badung Year 2018/2019 which has low critical thinking skills
\end{abstract}

Keywords: critical thinking skills, guided discovery learning, science learning outcomes 


\section{PENDAHULUAN}

Pembelajaran merupakan suatu proses interaksi komunikasi antara sumber belajar, guru dan peserta didik dan merupakan unsur yang sangat fundamental dalam setiap penyelenggaraan jenis dan jenjang pendidikan. Ini berarti berhasil atau tidaknya pencapaian tujuan pendidikan amat bergantung pada pada proses yang dialami peserta didik, baik ketika peserta didik berada disekolah maupun dilingkungan rumah atau keluarganya sendiri. Sehingga proses pembelajaran guru bukanlah sentral kegiatan belajar mengajar tetapi peserta didiklah yang menjadi pusat pembelajaran. Pembelajaran memiliki ciri utama adanya interaksi, selain itu pembelajaran memiliki komponen-komponen yang saling berhubungan yang bertujuan untuk mencapai tujuan pembelajaran. Berkaitan dengan hal tersebut, permasalahan yang sama juga terjadi di sekolah dasar gugus 07 abiansemal kabupaten badung pada siswa kelas IV yang mengidentifikasikan bahwa hasil belajar IPA siswa masih tergolong rendah, hal ini dapat dilihat dari hasil nilai ulangan akhir IPA semester I, dimana masih banyak anak yang berada pada criteria ketuntasan minimum (KKM) yang ditetapkan sekolah dengan rata-rata yaitu 77 . Terbukti dari masih adanya siswa yang kurang mencurahkan gagasan dan keputusan dalam proses pembelajaran. Untuk mengatasi permasalahan tersebut diperlukan model, strategi dan metode yang sesuai dalam proses pembelajaran. Salah satu strategi yang dapat diterapkan guru dalam pembelajaran IPA adalah strategi guided discovery learning. Dengan menerapkan strategi guided discovery learning dapat memberikan solusi dan suasana baru dalam proses pembelajaran.

Menurut Sapriati (2009: 1.28) ada dua macam atau jenis pembelajaran penemuan, yaitu: Model pembelajaran penemuan murni (free discovery) dan model pembelajaran penemuan terarah atau penemuan terbimbing (guided discovery). Model pembelajaran murni merupakan model pembelajaran penemuan tanpa adanya petunjuk atau arahan. Sedangkan model pembelajaran penemuan terarah/terbimbing (guided discovery) merupakan model pembelajaran yang membutuhkan peran guru sebagai fasilitator dalam proses pembelajarannya.

Pembelajaran penemuan terbimbing (guided discovery) lebih banyak diterapkan dibandingkan pembelajaran penemuan murni, karena dalam pembelajaran penemuan terbimbing guru akan memberikan petunjuk kepada siswa sehingga siswa akan lebih terarah dalam rangka mencapai tujuan yang telah ditetapkan. Menurut Eggen (2012: 201) selain mendorong pemahaman materi secara mendalam dan mengembangkan pemikiran siswa, model temuan terbimbing bisa efektif untuk meningkatkan motivasi siswa.

Melalui strategi guided discovery learning terhadap hasil belajar di tinjau dari berpikir kritis pada pembelajaran ipa diharapkan mampu meningkatkan aktivitas dan hasil belajar peserta didik khususnya di SD Negeri 2 Sedang. Alasan lainnya penelitian ini strategi guided discovery learning dapat melibatkan proses mental dan fisik melalui interaksi pesrta didik, peserta didik dengan guru, lingkungan, dan sumber belajar lainnya dalam rangka pencapaian tujuan pembelajaran.

Strategi guided discovery learning (penemuan terbimbing), dimana guru membantu peserta didik menemukan dan memecahkan masalah, sehingga fungsi guru berperan sebagai pembimbing, organisator dan fasilitator dengan memberikan kesempatan kepada peserta didik agar lebih aktif dan kreatif dalam pembelajaran, sehingga proses pembelajaran dapat terarah dan sesuai dengan tujuan pembelajaran yang akan dicapai. Melalui penerapan pembelajaran berbasis guided discovery learning peserta didik benar-benar dapat memahami suatu konsep atau rumus, sebab peserta didik mengalami sendiri proses untuk mendapatkan konsep atau 
rumus itu sendiri. Metode penemuan terbimbing (guided discovery) merupakan suatu metode pembelajaran yang dikembangkan berdasarkan pandangan kontruktivisme. Metode ini menekankan pada pentingnya pemahaman struktur atau ide-ide penting terhadap suatu disiplin ilmu yang melalui keterlibatan peserta didik secara aktif dalam proses pembelajaran. Pembelajaran berbasis guided discovery learning sangat cocok jika diimplementasikan dalam pembelajaran kurikulum 2013, terutama pada pembelajaran IPA yang menuntut peserta didik untuk mampu memahani konsep terlebih dahulu kemudian mampu memecahkan permasalahan yang terkait dengan materi yang telah dipelajari.

Peserta didik yang belum menguasai konsep, akan sulit ketika dihadapkan pada permasalahan yang sesungguhnya. Hal ini yang harus dilakukan guru agar peserta didik dapat memahami secara konsep dan praktik dengan menggunakan pembelajaran berbasis guided discovery learning. Menguasai konsep adalah kunci utama dalam penerapan pembelajaran dengan menggunakan guided discovery learning. Penerapan metode penemuan terbimbing mengembangkan kemampuan berpikir kritis peserta didik, menjadikan belajar sebagai kegiatan yang menyenangkan. Berdasarkan beberapa pendapat di atas, penulis menyimpulkan bahwa strategi guided discovery learning merupakan strategi pembelajaran yang dalam pelaksanaannya siswa berfikir sendiri sehingga dapat menemukan sebuah konsep, teori, pemecahan masalah, berdasarkan bimbingan atau arahan dari guru.

Belajar merupakan suatu proses yang sangat penting, karena melalui belajar, diharapkan dapat mencapai tujuan atau hasil belajar. Dengan hasil belajar tujuan pendidikan dapat diukur apakah telah tercapai ataukah belum tercapai. Keller (dalam Nashar, 2004: 77), memandang hasil belajar sebagai keluaran dari berbagai masukan. Berbagai masukan tersebut menurut Keller dapat dibedakan menjadi masukan pribadi (personal inputs) dan masukan dari lingkungan (environment inputs). Hasil belajar merupakan tujuan akhir dilaksanakannya kegiatan pembelajaran di sekolah. Hasil belajar dapat ditingkatkan melalui usaha sadar yang dilakukan secara sistematis mengarah kepada perubahan yang positif yang kemudian disebut dengan proses belajar.

Akhir dari proses belajar adalah perolehan suatu hasil belajar peserta didik. Hasil belajar peserta didik di kelas terkumpul dalam himpunan hasil belajar kelas. Semua hasil belajar tersebut merupakan hasil dari suatu interaksi tindak belajar dan tindak mengajar. Dari sisi guru, tindak mengajar diakhiri dengan proses evaluasi hasil belajar, sedangkan dari sisi peserta didik, hasil belajar merupakan berakhirnya penggal dan puncak proses belajar (Dimyati dan Mudjiono, 2009:3). Menurut Sudjana (2010:22) hasil belajar adalah kemampuan-kemampuan yang dimiliki siswa setelah ia menerima pengalaman belajarnya. Menurut Poerwanti (2009:7.4) keberhasilan siswa setelah mengikuti satuan pembelajaran tertentu kita sebut dengan keberhasilan hasil belajar.

Hasil belajar dapat tertuang dalam taksonomi Bloom, yakni dikelompokkan dalam tiga ranah (domain) yaitu, domain kognitif atau kemampuan berpikir, domain afektif atau sikap, dan domain psikomotor atau keterampilan. Sehubungan dengan itu, Gagne dalam Sudjana, (2010: 22) mengembangkan kemampuan hasil belajar menjadi lima macam antara lain:

(1) hasil belajar intelektual merupakan hasil belajar terpenting dari sistem lingsikolastik; (2) strategi kognitif yaitu mengatur cara belajar dan berfikir seseorang dalam arti seluas-luasnya termaksuk kemampuan memecahkan masalah; (3) sikap dan nilai, berhubungan dengan arah intensitas emosional dimiliki seseorang sebagaimana disimpulkan dari kecenderungan bertingkah laku terhadap orang dan kejadian; (4) informasi verbal, pengetahuan dalam arti informasi dan fakta; dan (5) keterampilan motorik yaitu kecakapan yang berfungsi untuk lingkungan hidup serta memprestasikan konsep dan lambang. 
Berdasarkan pendapat para ahli di atas, diatas disimpulkan bahwa hasil belajar adalah perubahan kemampuan yang diperoleh melalui pengalamanpengalaman setelah dilakukannya proses belajar.

Menggunakan pemikiran dalam tingkatan yang lebih tinggi dalam pembelajaran IPA memungkinkan siswa menemukan kebenaran dari informasi maupun fakta-fakta yang dialami siswa. Sehingga pembelajaran IPA menjadi lebih bermakna dan dapat membantu siswa memperoleh pemahaman yang mendalam serta siswa dapat menghadapi permasalahan-permasalahan yang terjadi dikehidupannya secara objektif. Dalam prakteknya di lapangan, siswa kurang diberikan kesempatan untuk mencurahkan gagasan dan juga keputusan dalam proses pembelajaran.

Pemahaman guru akan pengetahuan mengenai variasi strategi pembelajaran yang juga masih minim turut mendukung kemampuan berpikir kritis siswa menjadi kurang berkembang. Melihat masih rendahnya kemampuan berpikir kritis siswa ini, maka perlu adanya strategi pembelajaran yang dapat melatih kemampuan berpikir kritis siswa. Strategi guided discovery learning merupakan salah satu strategi yang cocok digunakan dalam pembelajaran IPA. Berdasarkan uraian latar belakang masalah yang telah peneliti paparkan di atas, maka timbul berbagai masalah yang dapat diidentifikasikan diantaranya sebagai berikut; (1) Kemampuan berpikir kritis Pada Pembelajaran IPA siswa Sekolah Dasar di Indonesia masih rendah; (2) Strategi pembelajaran yang selama ini dipakai masih kurang efektif untuk melatih Kemampuan berpikir kritis pada pembelajaran IPA siswa SD; (3) Pentingnya melatih kemampuan berpikir kritis siswa sejak dini; (4) Kemampuan berpikir kritis siswa terhambat akibat pembelajaran masih berorientasi pada hafalan; (5) Keunggulan dari strategi guided discovery learning; (6) Strategi guided discovery Learning berpengaruh positif terhadap Kemampuan berpikir kritis pada pembelajaran IPA siswa kelas IV SD.
Berdasarkan kajian di atas, dapat disimpulkan bahwa berpikir kritis adalah proses mental untuk menganalisis atau mengevaluasi informasi, informasi tersebut didapat dari hasil pengamatan, pengalaman, akal sehat, atau komunikasi. Berpikir kritis merupakan pengujian rasional terhadap ide, pengaruh, asumsi, prinsip, argument, kesimpulan, isu, pernyataan, keyakinan, dan aktivitas. Berpikir bukan suatu proses yang statis, tetapi selalu berubah secara konstan dan dinamis dalam setiap hari.

Paradigma baru dalam pendidikan bahwa berpikir kritis di butuhkan saat ini dalam kegiatan pembelajaran yang menekankan pada student centered menuntut adanya keaktifan dari siswa dalam proses pembelajaran. Kegiatan pembelajaran yang student centered akan membuat siswa menjadi lebih aktif dalam kegiatan pembelajaran dan mencari berbagai sumber informasi yang dapat digunakan dan relevan untuk menunjang kegiatan pembelajarannya. Maka dari itu revolusi industri 4.0 sangat berpengaruh saat ini dalam pendidikan, siswa lebih mudah mendapatkan informasi melalui internet baik itu dalam bentuk data foto, bahkan video untuk menunjang Kegiatan pembelajaran menjadi lebih bermakna dan siswa tidak hanya sekedar menghafal materi yang diajarkan. Hal ini akan berakibat pada pemahaman siswa yang menjadi lebih baik dan berimbas pula pada meningkatnya kemampuan pemecahan masalah matematika siswa. Guru juga memiliki peran guna menunjang dan meningkatkan keaktifan siswa dalam kegiatan pembelajaran. Pemilihan strategi pembelajaran yang tepat juga merupakan suatu hal yang dapat meningkatkan aktivitas belajar IPA siswa dan kemampuan berpikir kritis siswa.

Pada praktiknya di sekolah, siswa mengalami kesulitan dalam berpikir kritis. Faktor penyebab siswa mengalami kesulitan dalam kemampuan berpikir kritis pada pembelajaran IPA, dapat bersumber dari siswa maupun guru. Faktor yang bersumber dari siswa yaitu siswa terbiasa belajar dengan cara menghafal dan kurangnya minat serta motivasi siswa 
untuk belajar. Sedangkan faktor penyebab yang bersumber dari guru, yaitu faktor model pembelajaran yang kurang membangun kemampuan berpikir kritis pada pembelajaran IPA. Strategi ini kemudian dikembangkan dari keterlibatan siswa dari proses berpikir setelah membaca, selanjutnya berbicara, dan membagi ide (sharing) dari satu individu pada teman lain atau dalam kelompok kemudian mengungkapkan dalam tulisan atau rangkuman sesuai dengan kreativitasnya. Pada proses belajar terjadi aktivitas berpikir, berkomunikasi dan mengkonstruksi ide berdasarkan pemahaman dan pengetahuan yang diperolehnya kemudian mendapatkan hasil belajar. Dengan strategi pembelajaran ini diharapkan siswa terlibat aktif, baik secara individual maupun dalam kelompok belajar.

Berdasarkan latar belakang tersebut maka dilakukan penelitian berjudul : "Pengaruh Strategi Guided Discovery Learning Terhadap Hasil Belajar IPA Ditinjau Dari Kemampuan Berpikir Kritis Siswa Kelas IV SD Gugus VII Abiansemal Kabupaten Badung".

\section{METODE PENELITIAN}

Penelitian yang dilakukan ini
merupakan penelitian Penelitian eksperimen bertujuan untuk menguji pengaruh variabel-variabel bebas terhadap variabel terikat. Rancangan penelitian ini menggunakan eksperimen semu (quasi eksperimen). Desain eksperimen semu yang digunakan adalah Post Test Only Control Group Design yaitu desain yang terdiri dari dua kelompok yakni kelompok eksperimen dan kelompok kontrol, kelompok eksperimen dan kontrol tanpa melalui pratest hanya dikenakan postest saja.

Pada rancangan ini terlihat bahwa rangkaian kegiatan untuk kelompok eksperimen dan kontrol sama-sama diawali dengan pengacakan kelas atau random sampling, tanpa pemberian pratest langsung pada pemberian perlakuan atau treatment dan diakhiri dengan pemberian post-test. Rancangan kegiatan pada kelas eksperimen dan kelas kontrol memiliki perbedaan mendasar yang terletak pada perbedaan perlakuannya. Pada kelompok eksperimen mendapatkan perlakuan khusus berupa penerapan strategi guided discovery learning dan berpikir kritis sedangkan pada kelompok kontrol tidak mendapatkan perlakuan khusus, namun bukan berarti pada kelompok kontrol tidak ada kegiatan pembelajaran melainkan kegiatan pembelajaran dilakukan dengan menggunakan pembelajaran konvensional.

Kelas yang terpilih sebagai kelas eksperimen dan kelas kontrol terbentuk tanpa adanya campur tangan peneliti dan tidak dilakukan pengacakan individu untuk mencegah kemungkinan objek mengetahui dirinya dilibatkan dalam penelitian sehingga penelitian ini benarbenar menggambarkan pengaruh perlakuan yang diberikan yaitu pengaruh strategi guided discovery learning dan berpikir kritis terhadap hasil belajar IPA siswa. Pada saat pelaksanaan eksperimen, treatment (tindakan) diadakan sebanyak 8 kali pertemuan dan pada pengakhiran baik kelompok eksperimen dan kelompok kontrol samasama diberikan post-test sesuai dengan materi yang telah diajarkan. Setelah hasil post-test diperoleh nilai dianalisis dengan anava 2 jalur.

Populasi adalah keseluruhan obyek dalam suatu penelitian. Pendapat tersebut didukung oleh Sugiyono (2011) yang menyatakan "populasi ialah wilayah generalisasi yang terdiri atas obyek/subyek yang mempunyai kualitas dan karakteristik tertentu yang ditetapkan oleh peneliti untuk dipelajari dan kemudian ditarik kesimpulannya". Populasi dalam penelitian ini adalah seluruh siswa kelas IV SD di gugus 07 abiansemal Tahun Pelajaran 2018/2019, data ini didapatkan dari hasil observasi langsung di SD Gugus 07 abiansemal dengan melakukan wawancara pada kepala sekolah masingmasing sekolah.

Pengambilan sampel pada penelitian ini dilakukan dengan teknik random sampling. Teknik random sampling adalah penarikan sampel secara sederhana 
dengan cara random (Dantes, 2012:41). Dalam penelitian ini yang dirandom adalah kelas sebagai intaks grup. Berdasarkan jenis-jenis teknik sampling di atas, pengambilan sampel pada penelitian ini dilakukan dengan teknik random sampling. Random sampling dilakukan pada kelas.

Untuk menguji kesetaraan sampel digunakan uji Anava Satu Jalan. Uji Anava Satu Jalan pada penelitian ini menggunakan bantuan SPSS 17.0 for Windows. Kriteria yang digunakan adalah: apabila $\mathrm{F}$ hitung $>\mathrm{F}$ tabel pada taraf signifikansi $5 \%$, maka seluruh sampel pada penelitian ini tidak setara, sedangkan apabila $\mathrm{F}$ hitung $<\mathrm{F}$ tabel pada taraf signifikansi $5 \%$, maka seluruh sampel pada penelitian ini setara.

Variabel bebas dalam penelitian ini adalah pengaruh strategi Guided Discovery Learning dan pembelajaran konvensional. Pengaruh strategi Guided Discovery Learning dilibatkan pada kelompok eksperimen, sedangkan pembelajaran konvensional dilibatkan pada kelompok kontrol. Dalam penelitian ini, variabel moderatornya adalah kemampuan berpikir kritis. Variabel terikat dalam penelitian ini adalah hasil belajar IPA pada siswa kelas IV SD Gugus VII Abiansemal Badung yang ditunjukkan dalam skor tes akhir siswa.

Data yang dikumpulkan dalam penelitian ini adalah data tentang hasil belajar IPA peserta didik kelas IV di SD Gugus 07 abiansemal setelah diterapkannya pendekatan pengaruh strategi guided discovery learning.
Data yang diperoleh melalui hasil penelitian ini adalah dalam bentuk deskriptif kuantitatif dengan mencari harga rerata (Mean), standar deviasi (SD), modus $(M o)$, dan median $(M e)$ setiap variabel yang diteliti kemudian dikonversikan melalui pedoman klasifikasi penilaian skala lima. Teknik statistik inferensial digunakan untuk menguji kebenaran hipotesis penelitian dan hasilnya dapat digeneralisasikan. Untuk mengetahui uji statistik parametrik bisa dilakukan atau tidak, sebelum dilakukan uji hipotesis terlebih dahulu dilakukan uji prasyarat analisis normalitas dan homogenitas.

Analisis statistik yang digunakan untuk menguji hipotesis penelitian pertama dan kedua adalah ANAVA dua jalur. Jika hipotesis kedua signifikan atau $\mathrm{HO}$ ditolak, yang artinya terdapat interaksi antara pengaruh guided discovery learning dengan berpikir kritis dalam pengaruhnya terhadap hasil belajar IPA siswa, maka akan dilakukan uji untuk hipotesis 3 dan 4 . Jika hasil interaksi menyatakan signifikan yang berarti ada perbedaan pengaruh perlakuan terhadap hasil belajar masing-masing kelompok. maka dilanjutkan dengan uji $t$-scheffe.

\section{HASIL DAN PEMBAHASAN}

Dalam penelitian ini, objek penelitiannya adalah perbedaan hasil belajar IPA ditinjau dari kemampuan berpikir kritis. Perhitungan ukuran senteral (mean, modus, median) dan ukuran penyebaran data dapat dilihat pada Tabel 01 berikut.

Tabel 01 Rekapitulasi Hasil Perhitungan Skor Hasil Belajar IPA

\begin{tabular}{|c|c|c|c|c|c|c|c|c|}
\hline Statistik Data & A1 & A2 & B1 & B2 & A1B1 & A1B2 & A2B1 & A2B2 \\
\hline $\mathrm{N}$ & 38 & 38 & 38 & 38 & 19 & 19 & 19 & 19 \\
\hline Mean & 20,37 & 18,66 & 23,79 & 15,24 & 27,32 & 13,42 & 20,26 & 17,05 \\
\hline Median & 20,50 & 18 & 24,50 & 16 & 27 & 14 & 20 & 17 \\
\hline Mode & 14 & 17 & 26 & 16 & 26 & 14 & 18 & 17 \\
\hline Std. Deviation & 7,35 & 2,76 & 4,19 & 2,83 & 1,77 & 2,43 & 2,58 & 1,89 \\
\hline Variance & 53,97 & 7,64 & 17,52 & 8,02 & 3,12 & 5,92 & 6,65 & 3,61 \\
\hline Range & 21 & 11 & 15 & 12 & 6 & 8 & 10 & 7 \\
\hline Minimum & 9 & 14 & 15 & 9 & 24 & 9 & 15 & 14 \\
\hline Maximum & 30 & 25 & 30 & 21 & 30 & 17 & 25 & 21 \\
\hline Sum & 774 & 709 & 904 & 579 & 519 & 255 & 385 & 324 \\
\hline
\end{tabular}


Keterangan:

$$
\begin{aligned}
& \text { A1 = Kelompok siswa yang diajar } \\
& \text { dengan strategi guided } \\
& \text { discovery learning }
\end{aligned}
$$

A2 = Kelompok siswa yang diajar dengan strategi pembelajaran konvensional

B1 = Kelompok siswa yang mempunyai kemampuan berpikir kritis tinggi

B2 = Kelompok siswa yang mempunyai kemampuan berpikir kritis rendah

A1B1 = Kelompok siswa yang diajar dengan strategi guided discovery learning dan mempunyai kemampuan berpikir kritis tinggi.

A1B2 = Kelompok siswa yang diajar dengan strategi guided discovery learning dan mempunyai kemampuan berpikir kritis rendah

A2B1 = Kelompok siswa yang diajar dengan strategi pembelajaran konvensional dan mempunyai kemampuan berpikir kritis tinggi.

A2B2 = Kelompok siswa yang diajar dengan strategi pembelajaran konvensional dan mempunyai kemampuan berpikir kritis rendah.

Hasil analisis data dalam penelitian ini dapat di deskripsikan sebagai berikut :

Hipotesis pertama, berbunyi Perbedaan Hasil Belajar IPA antara Siswa yang Mengikuti Strategi Guided Discovery Learning dengan Siswa yang Mengikuti Strategi Pembelajaran Konvensional pada Siswa Kelas IV SD Gugus VII Abiansemal Kabupaten Badung. Berdasarkan hasil analisis data telah terbukti bahwa hasil belajar IPA antara siswa yang mengikuti strategi guided discovery learning dengan siswa yang mengikuti strategi pembelajaran konvensional pada siswa kelas IV SD Gugus VII Abiansemal Kabupaten Badung lebih baik dibandingkan dengan siswa yang mengikuti strategi pembelajaran konvensional. Hal ini ditunjukkan dengan rata-rata hasil belajar siswa yang mengikuti pembelajaran dengan strategi guided discovery learning dengan skor rata-rata 20,36 lebih tinggi daripada hasil belajar siswa yang mengikuti pembelajaran dengan strategi pembelajaran konvensional dengan skor rata-rata 18,66 . Jadi dalam perbandingan antara strategi guided discovery learning dengan strategi pembelajaran konvensional, terdapat pengaruh model pembelajaran terhadap hasil belajar siswa. Dengan kata lain, ada perbedaan antara strategi guided discovery learning dan strategi pembelajaran konvensional dalam pembelajaran IPA. Dalam pembelajaran IPA, strategi guided discovery learning secara keseluruhan terbukti lebih baik dan efektif dibandingkan dengan strategi pembelajaran konvensional.

Pembelajaran discovery (penemuan) adalah model yang mengajar dan mengatur pengajaran sehingga anak memperoleh pengetahuan yang sebelumnya belum diketahui. discovery adalah proses mental pada siswa mampu mengasimilasikan suatu konsep atau prinsip. Proses mental yang di maksud antara lain mengamati, mencerna, mengerti, menggolong-golongkan, membuat dugaan, menjelaskan, mengukur, membuat kesimpulan dan sebagainya. Guru hanya membimbing. Pada siswa SD, model yang digunakan adalah guided discovery (penemuan terbimbing) hal ini dikarenakan siswa masih memerlukan bantuan guru sebelum menjadi penemuan murni. dapat dilihat dari proses membaca suatu teks bacaan, suatu materi pelajaran kemudian membuat catatan apa yang telah dibaca. Dalam tahap ini, siswa secara inidividu memikirkan kemungkinana jawaban (model pembelajaran penyelesaian), membuat catatan apa yang telah dibaca. dalam tahap ini, siswa secara individu memikirkan kemungkinan jawaban (model pembelajaran penyelesaian), membuat catatan apa yang telah dibaca, baik itu berupa apa yang diketahuinya. Dengan model pembelajaran ini seorang siswa 
akan dilatih kemampuannya dalam berpikir kritis. Sehingga, dengan latihan yang memanfaatkan lingkungan sekitar yang sering ditemui akan membuat siswa lebih cepat memahami pembelajaran dan akan menjadi pembelajaran yang bermakna.

Sedangkan pada pembelajaran konvensional yang digunakan sehari-hari dalam proses pembelajaran. Pembelajaran konvensional dalam pelaksanaannya tidak beranjak dari permasalahan kontekstual, terlebih menuntun dalam menghasilkan karya nyata berupa produk dalam proses pembelajaran. Lazimnya, pembelajaran konvensional tidak menantang siswa dalam berproses untuk memecahkan permasalahan nyata. Pembelajaran konvensional beranjak dari dominasi guru terhadap kelas dengan karakteristik menjelaskan pengertian serta konsep, memberi contoh, latihan dan pada akhirnya siswa diberikan soal untuk dikerjakan sebagai penerapan dari konsep-konsep yang telah diajarkan guru. Pada pembelajaran konvesional siswa tidak terlibat dalam menemukan sendiri konsep matematika ataupun beraktivitas untuk menghasilkan produk, sehingga pembelajaran terkesan abstrak dan sulit bagi siswa.

Hasil temuan dalam penelitian ini sejalan dengan penelitian yang dilakukan oleh Tiana (2015) "Pengaruh Strategi Guided Discovery Learning Terhadap Kemampuan Berpikir Kritis Pada Pembelajaran IPA Siswa Kelas V Sekolah Dasar" Penelitian eksperimen ini bertujuan untuk mengetahui pengaruh strategi guided discovery learning terhadap Kemampuan berpikir kritis pada pembelajaran IImu Pengetahuan Alam siswa kelas V SD. Menyatakan bahwa strategi guided discovery learning berpengaruh signifikan terhadap Kemampuan berpikir kritis pada pembelajaran IImu pengetahuan alam siswa kelas V Sekolah Dasar.

Dari uraian dan temuan yg relevan tersebut, jelas terlihat bahwa hasil belajar siswa yang megikuti strategi guided discovery learning lebih baik daripada hasil belajar siswa yang diajar menggunakan strategi pembelajaran konvensional.

Hipotesis kedua, berbunyi Pengaruh Interaksi Antara Strategi Guided Discovery Learning dengan Kemampuan Berpikir Kritis Terhadap Hasil Belajar IPA Siswa Kelas IV SD Gugus VII Abiansemal Kabupaten Badung. Analisis data telah membuktikan bahwa terdapat pengaruh interaksi antara strategi guided discovery learning dengan kemampuan berpikir kritis terhadap hasil belajar IPA Siswa Kelas IV SD Gugus VII Abiansemal Kabupaten Badung. Hal ini ditunjukkan dengan nilai rata-rata hasil belajar siswa yang mengikuti pembelajaran dengan strategi guided discovery learning dengan skor rata-rata 20,37 lebih tinggi daripada siswa yang mengikuti pembelajaran dengan strategi pembelajaran konvensional. Jadi terdapat bahwa pengaruh interaksi antara strategi guided discovery learning dengan kemampuan berpikir kritis terhadap hasil belajar IPA siswa kelas IV SD Gugus VII Abiansemal Kabupaten Badung.

Berpikir kritis merupakan salah satu kemampuan berpikir tingkat tinggi. Tujuan awal berpikir kritis adalah menyingkapkan kebenaran dengan menyingkirkan semua yang salah agar kebenaran dapat terlihat. Berpikir kritis adalah berpikir secara beralasan dan reflektif dengan menekankan pada pembuatan keputusan tentang apa yang harus dipercayai atau dilakukan. Kemampuan berpikir kritis setiap siswa berbeda-beda, hal ini disebabkan oleh perbedaan kemampuan siswa dalam hal memberikan argumen, melakukan deduksi, melakukan induksi, melakukan evaluasi dan memutuskan serta melaksanakan solusi Pembelajaran konvensional yang digunakan sehari-hari dalam proses pembelajaran, dalam pelaksanaannya tidak bermula dari permasalahan kontekstual. Pembelajaran ini cenderung menuntun dalam menghasilkan karya nyata berupa produk dalam proses pembelajaran. Biasanya, pembelajaran konvensional tidak menantang siswa dalam berproses untuk memecahkan permasalahan nyata. 
Pembelajaran konvensional didominasi guru terhadap kelas dengan karakteristik menjelaskan pengertian serta konsep, memberi contoh, latihan dan pada akhirnya siswa diberikan soal untuk dikerjakan sebagai penerapan dari konsep-konsep yang telah diajarkan guru.

Pada pembelajaran konvesional siswa tidak terlibat dalam menemukan sendiri konsep. Siswa yang memiliki kemampuan berpikir kritis rendah kurang menunjukkan sikap antusias dan aktif untuk mengikuti pembelajaran. Siswa ini akan cenderung menerima dan mengikuti arahan dari guru. Siswa akan mengalami beberapa kendala dalam aktivitas mengkoneksikan informasi lama dengan informasi yang baru (connecting), selanjutnya mengorganisasikan informasiinformasi yang diperoleh seperti konsep apa yang diketahui, konsep apa yang dicari, dan keterkaitan antar konsep apa saja yang ditemukan (organizing), memikirkan kembali informasi yang didapat dan dipahami (reflekting), serta menggunakan pengetahuan tersebut dalam pemecahan masalah yang serupa dengan masalah sebelumnya (extending).

Hasil temuan dalam penelitian ini sejalan dengan hasil penelitian yang dilakukan oleh Maulidar (2016) yang berjudul "Pengaruh Penerapan Model Pembelajaran Guided Discovery Terhadap Kemampuan Pemahaman Konsep Dan Ketrampilan Berpikir Kritis Siswa Smp Pada Materi Kemagnetan" juga relevan dengan penelitian ini, karena penelitian yang dilakukan oleh Maulidar menunjukan bahwa terjadi peningkatan Berpikir kritis pada siswa.

Berdasarkan pernyataan di atas, dapat dikatakan bahwa terdapat pengaruh interaksi antara strategi guided discovery learning dengan kemampuan berpikir kritis terhadap hasil belajar IPA.

Hipotesis ketiga, berbunyi terdapat Perbedaan Hasil Belajar IPA Antara Siswa yang Mengikuti Strategi Guided Discovery Learning dengan Siswa yang Mengikuti Strategi Pembelajaran Konvensional pada Siswa Kelas IV SD Gugus VII Abiansemal Kabupaten Badung
Pada Siswa yang Memiliki Kemampuan Berpikir Kritis Tinggi. Berdasarkan analisis data ternyata terdapat perbedaan hasil belajar IPA antara siswa yang mengikuti strategi guided discovery learning dengan siswa yang mengikuti strategi pembelajaran konvensional pada siswa kelas IV SD Gugus VII Abiansemal Kabupaten Badung pada siswa yang memiliki kemampuan berpikir kritis tinggi. Siswa yang memiliki kemampuan berpikir kritis tinggi cenderung menunjukkan sikap antusias dan aktif untuk mengikuti pembelajaran. Strategi guided discovery learning dapat melibatkan siswa secara langsung untuk memberikan jawaban. sehingga dapat mengoptimalkan kemampuan berpikir kritis siswa. Di sisi lain pada penerapan pembelajaran konvensional, dimana pembelajaran didominasi oleh penjelasan guru dan siswa menerima materi yang dijelaskan guru (teacher center), menyebabkan siswa kurang aktif dalam proses pembelajaran. Siswa dengan kemampuan berpikir kritis tinggi tidak akan dapat mengembangkan kemampuannya karena tidak ada aktivitas yang membangkitkan kemampuan berpikir kritis terhadap hasil belajar IPA Siswa yang memiliki kemampuan berpikir kritis tinggi cenderung menunjukkan sikap antusias dan aktif untuk mengikuti pembelajaran.

Dari uraian di atas tergambar jelas bahwa terdapat perbedaan hasil belajar IPA antara siswa yang mengikuti strategi guided discovery learning dengan siswa yang mengikuti strategi pembelajaran konvensional pada siswa kelas IV SD Gugus VII Abiansemal Kabupaten Badung pada siswa yang memiliki kemampuan berpikir kritis tinggi.

Hipotesis keempat, berbunyi terdapat Perbedaan Hasil Belajar IPA antara Siswa yang Mengikuti Strategi Guided Discovery Learning dengan Siswa yang Mengikuti Strategi Pembelajaran Konvensional pada Siswa Kelas IV SD Gugus VII Abiansemal Kabupaten Badung pada Siswa yang Memiliki Kemampuan Berpikir Kritis Rendah. Berdasarkan analisis data 
ternyata terdapat perbedaan hasil belajar IPA antara siswa yang mengikuti strategi guided discovery learning dengan siswa yang mengikuti strategi pembelajaran konvensional pada siswa kelas IV SD Gugus VII Abiansemal Kabupaten Badung pada siswa yang memiliki kemampuan berpikir kritis rendah. Siswa yang memiliki kemampuan berpikir kritis rendah lebih baik hasil belajarnya dibandingkan dengan siswa yang memiliki cinta lingkungan tinggi pada strategi pembelajaran konvensional.

Siswa yang memiliki kemampuan berpikir kritis rendah kurang menunjukkan sikap antusias dan aktif untuk mengikuti pembelajaran. Siswa ini akan cenderung menerima dan mengikuti arahan dari guru. Siswa akan mengalami beberapa kendala dalam aktivitas mengkoneksikan informasi lama dengan informasi yang baru (connecting), selanjutnya mengorganisasikan informasi-informasi yang diperoleh seperti konsep apa yang diketahui, konsep apa yang dicari, dan keterkaitan antar konsep apa saja yang ditemukan (organizing), memikirkan kembali informasi yang didapat dan dipahami (reflekting), serta menggunakan pengetahuan tersebut dalam berpikir kritis yang serupa dengan masalah sebelumnya (extending). Maka muncullah dugaan bahwa hasil belajar IPA siswa yang memiliki kemampuan berpikir kritis rendah yang belajar melalui penerapan strategi guided discovery learning lebih rendah dibandingkan dengan siswa yang belajar melalui pembelajaran konvensional. Di sisi lain pada penerapan pembelajaran konvensional, dimana pembelajaran didominasi oleh penjelasan guru dan siswa menerima materi yang dijelaskan guru (teacher center), menyebabkan siswa kurang aktif dalam proses pembelajaran.

Berdasarkan pernyataan di atas, bahwa hasil belajar IPA siswa yang memiliki kemampuan berpikir kritis rendah yang belajar melalui penerapan strategi guided discovery learning lebih rendah dibandingkan siswa yang belajar melalui pembelajaran konvensional.
Secara keseluruhan hasil penelitian ini, dapat disimpulkan bahwa strategi guided discovery learning sangat efektif diterapkan untuk meningkatkan kemampuan berpikir kritis dan hasil belajar IPA siswa.

\section{PENUTUP}

Berdasarkan empat temuan dari hasil pengujian hipotesis seperti disajikan pada bab IV, maka dalam penelitian ini diperoleh empat simpulan sebagai berikut:

$\begin{array}{lrr}\text { Pertama, } & \text { Temuan } & \text { penelitian } \\ \text { menunjukkan } & \text { bahwa } & \text { terdapat }\end{array}$ perbedaan hasil belajar IPA antara siswa yang mengikuti strategi guided discovery learning dengan siswa yang mengikuti strategi pembelajaran konvensional pada siswa kelas IV SD Gugus VII Abiansemal Kabupaten Badung.

Kedua, Temuan penelitian menunjukkan pengaruh interaksi antara strategi guided discovery learning dengan kemampuan berpikir kritis terhadap hasil belajar IPA siswa kelas IV SD Gugus VII Abiansemal Kabupaten Badung.

Ketiga, Temuan penelitian menunjukkan untuk siswa yang memiliki kemampuan berpikir kritis tinggi, ada perbedaan hasil belajar IPA antara siswa yang mengikuti strategi guided discovery learning dengan siswa yang mengikuti strategi pembelajaran konvensional pada siswa kelas IV SD Gugus VII Abiansemal Kabupaten Badung.

Keempat, Temuan penelitian menunjukkan untuk siswa yang memiliki kemampuan berpikir kritis rendah, ada perbedaan hasil belajar IPA antara siswa yang mengikuti strategi guided discovery learning dengan siswa yang mengikuti strategi pembelajaran konvensional pada siswa kelas IV SD Gugus VII Abiansemal Kabupaten Badung.

Berkenaan dengan hasil penelitian dan manfaat yang diperoleh maka beberapa saran yang dapat diajukan adalah sebagai berikut: 
Pertama, Strategi guided discovery learning perlu dikenalkan dan dikembangkan lebih lanjut kepada para guru, siswa, dan praktisi pendidikan lainnya sebagai strategi pembelajaran IPA alternatif setelah sekian lama menggunakan strategi konvensional.

Kedua, Penelitian lanjutan yang berkaitan dengan penerapan strategi guided discovery learning perlu dilakukan dengan melibatkan materi IPA yang lain dengan melibatkan sampel yang lebih luas.

\section{DAFTAR RUJUKAN}

Anderson, L.W., dan Krathwohl, D.R. 2001. A Taxonomy for Learning, Teaching, and Assesing: $A$ Revision of Bloom's Taxonomy of Educatioanl Objectives. New York: Addison Wesley Longman, Inc.

Candiasa, I. M. 2010. Statistik Unvariant dan Bivariat Disertai Aplikasi SPSS. Singaraja: Unit Penerbit Universitas Pendidikan Ganesha.

Dantes, Nyoman. 2012 Metodelogi Penelitian, Andi: Yogyakarta

Dimyati dan Mudjiono, 2009:3

Ennis, Robert H.2011. The Nature of Critical Thingking. Di unduh pada 1 April 2019. https://education.illinois.edu/docs /default-source/facultydocuments/robertennis/thenatureofcriticalthinking 51711_000.pdf?sfvrsn=7bb5128 822

Gregory., R. 2000. Psychology testing (history principles, and applications). Boston allyn and bacon.

Hajar. 2017. Learning Geometry through Discovery Learning Using a Scientific Approach.
International Journal of
Instruction. University of
Muhammadiyah Malang
Indonesia. Vol.10, No.1.

Huda. 2014. Model - Model Pengajaran dan Pembelajaran. Yogyakarta

Istiqomah. 2017. Pengembangan lembar kerja peserta didik Tematik Berbasis guided discovery learning. Artikel Universitas Lampung.

Kementerian Pendidikan dan Kebudayaan. 2014. Materi Pelatihan Implementasi Kurikulum 2013. Jakarta.

Kementrian Riset Indonesia. 2018. Proses pembelajaran digital dalam era revolusi industry 4.0. artikel file:///D:/KemenristekdiktiMempersiapkan-SDM-Indonesiadi-Era-Industri-4.0.pdf (diakses pada 19 Desember 2018).

Khabibah,norman elok. Kuswanti ,Nur. 2016. Keefektifan modul berbasis guided discovery pada materi respiratory sytem. Jurnal volume 1. Universitas Negeri Surabaya.

Maulidar. 2016. Pengaruh Penerapan Model Pembelajaran Guided Discovery Terhadap Kemampuan Pemahaman Konsep Dan Ketrampilan Berpikir Kritis Siswa Smp Pada Materi Kemagnetan.

Mawadati Nugroho, Maulida. 2018. Pengembangan Modul Ipa Berbasis Guided Discovery Learning (GDL) Dengan Tema Fotosintesis Untuk Meningkatkan Keterampilan Proses Sains Siswa SMP/Mts Kelas VIII SMP Al Ma'rufiyyah Tempuran. Jurnal Universitas 
Sebelas Maret Surakarta Vol.7, No.1. (diakses pada 17 Desember 2018).

Nurdiyansyah. 2016. Inovasi Pembelajaran Sesuai Kurikulum 2013. Sidoarjo. Nizamia Learning Center

Pedoman Penulisan Tesis Program Pascasarjana Universitas Pendidikan Ganesha (Edisi Revisi). 2016. FIP Undiksha: Universitas Pendidikan Ganesha.

Rachmadtullah, Reza. 2015. Kemampuan Berpikir Kritis Dan Konsep Diri Dengan Hasil Belajar Pendidikan Kewarganegaraan Siswa Kelas $\checkmark$ Sekolah Dasar. Jurnal Pendidikan Dasar Universitas Terbuka Jakarta. Volume 6 Edisi 2. Tersedia pada http://journal.unj.ac.id/unj/index. php/jpd/article/view/493/428 (diakses pada 20 November 2018).

Rusman. 2017. Belajar dan Pembelajaran. Jakarta: Kencana.

Sucipta. 2018. Metode Guided Discovery Learning terhadap Tingkat Berpikir Kritis Siswa Dilihat dari Motivasi Belajar. Indonesian Journal of Economics Education Vol.1 no. 1. (diakses pada 22 November 2018).

Sudjana, N. 1991. Dasar-dasar Proses

Belajar Mengajar. Sinar Baru,

Bandung: Cet III.

Sudjana, N. (2013). Penilaian Hasil Proses Belajar Mengajar. Bandung: PT. Remaja Rosdakarya
Suharsimi. 2006. Dasar-Dasar Evaluasi Pendidikan. Jakarta: Bumi Aksara.

Tiana, Neris Lendi. 2015. Pengaruh Strategi Guided Discovery Learning Terhadap Kemampuan Berpikir Kritis Pada Pembelajaran IPA Siswa Kelas V Sekolah Dasar. Jurnal Pendidikan Dasar. Universitas Negeri Jakarta. Volume 6 Edisi 2. Tersedia pada http://journal.unj.ac.id/unj/index.p hp/jpd/article/view/491/426 (diakses pada 11 April 2018) .

Triana, Desi. 2017. Pengembangan Lembar Kegiatan Peserta Didik Berbasis Guided Discovery Learning Di Sekolah Dasar. Artikel Universitas Lampung. (diakses pada 20 November 2018).

Trianto. (2010). Model Pembelajaran Terpadu: Konsep, strategi, dan Impelemtasinya dalam Kurikulum Tingkat Satuan Pendidikan (KTSP). Jakarta: PT. Bumi Aksara. 